\title{
Blodpropp i øyet
}

Da øyelegene i 1920-årene hadde sine møter, drøftet de brillesedler og demonstrerte pasienter. I Tidsskriftet nr. 8/1923 er flere pasienthistorier publisert. Her gjengis en av dem. Tromboserisikoen er forhøyet i forbindelse med svangerskap, men i dette tilfellet inntraff hendelsen nokså lenge etter fødselen. Interessant er den knappe skildringen av tilværelsen på et mødrehjem, denne kvinnen «levet under gode forhold, aldrig tungt arbeide». De første norske mødrehjem ble opprettet på slutten av 1800-tallet. De som hadde havnet i uløkka, skulle som vederlag for oppholdet gjøre nytte for seg. Av beskrivelsen kan man slutte at oppgavene blant annet besto av husarbeid og oppvartning av de sengeliggende (Tidsskr Nor Lægeforen 1923; 43: 461-3).

\section{Oftalmologisk forening i Kristiania.}

\author{
Forhandlinger $\mathrm{i}$ andet halvaar 1920.
}

31 te møte $28 \mathrm{de} \mathrm{oktober} 1920$.

I. S c høitz demonstrerte to patienter :

1) Synligembolus i retinal arteriegren. En 18aarig ugift I para hadde alltid været frisk, svangerskap og fødsel forløp uten komplikationer, aldrig albumin i urinen. Hun reiste p. p. til et mødrehjem, hvor hun i flere maaneder levet under gode forhold, aldrig tungt arbeide, velbefinnende ; ammet selv sit barn. 4 maaneder p. p. blev hun en dag totalt blind, angivelig paa begge øine, men fik efter faa minutter synet tilbake. Fordi det senere holdt sig en generende skygge for venstre øie, møtte hun den følgende dag paa klinikken med en oftalmoskopisk synlig embolus i arteria retinalis inferior medialis og en synsdefekt svarende hertil.

De nærmere enkeltheter ved hændelsen var følgende : Hun sprang en morgen raskt op trappen fra kjelder til 3dje etage med et frokostbret til en sengeliggende, gik hurtig hen til sengen, bøiet sig ned og satte brettet fra sig paa en lav stol. Idet hun rettet sig op igjen, blev det plutselig ganske mørkt for begge øine — «det blev sort som natten» - hun blev ræd, begynte at graate og spurte den syke, om hun virkelig hadde øinene aapne. Derefter vendte hun sig mot vinduet, som hun ikke engang kunde skimte, og mens hun stod slik uten at vove at røre eller gni øinene, begynte hun litt efter litt at se lys, og efter etpar minutters forløp saa hun næsten helt klart igjen. Under denne eiendommelige hændelse, som varte i høiden 5 minutter, hadde hun ikke hodepine, var ikke svimmel eller uvel, og følte sig ogsaa senere helt frisk.

Ved øienundersøkelsen 24 timer senere var der intet at bemerke ved høire øie. I venstre fundus saaes en papilleradius fra papillekanten et stykke av arteria inf. med. skinnende hvit, i en vel papilleradius' utstrækning (se fig. 2), blodsøilen centralt og perifert for det hvite parti var helt ubrutt, og karret saa her ganske ut som de øvrige arterier i øienbunden, dog var farven maaske litt mørkere. Øienbunden forøvrig var normal, ingen hæmorragier, intet ødem. Visus var med korrigerende glas $6 / 12$, som paa det andet øie. Urinen var fysiologisk, blodtrykket 120 R. R. Dagen efter var billedet litt forandret; det skinnende hvite parti saa vistnok ganske ut som før, men perifert for dette var arterien blit smalere og mørkere, litt mørkere end en vene, og hist
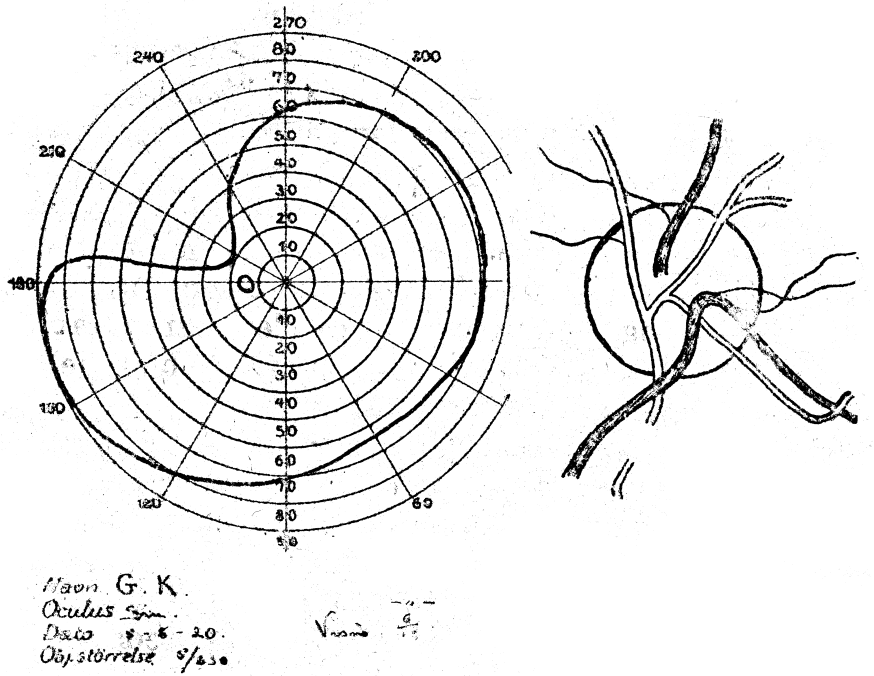

Fig. 2.

og her saaes hvite refleksprikker langs arterien, som om blodsøilen begyndte at dele sig op. To dager senere, fire dager efter hændelsen, var billedet atter forandret, men paa en helt uventet maate, idet det skinnende hvite parti nu var helt borte og arterien saa fuldstændig normal ut i hele sin længde, den var av samme farve som de øvrige arterier, og det saa ut som om blodsøilen var helt ubrutt ; men synsfeltdefekten var helt som før. Visus $6 / 8$ paa hvert øie. Idag - 3 maaneder senere (og likeledes efter $1 \frac{1}{2} 2$ aars forløp) er øienbundbilledet atter forandret ; man ser nu art. inf. med. av et helt normalt utseende paa papillen og intil den like utenfor papillekanten forsvinder under venen; men herfra og videre utover er den bare saavidt synlig som en ganske fin traad, som mere perifert blir helt usynlig. Uforandret visus og synsfelt. 